\title{
ANALISIS TINDAK TUTUR LOKUSI DALAM VIDEO “JANGAN LELAH BELAJAR_B.J. HABIBIE” PADA SALURAN YOUTUBE SANG INSPIRASI
}

\author{
Egi Nur Aini ${ }^{1}$, Asep Purwo Yudi Utomo ${ }^{2}$ \\ Universitas Negeri Semarang \\ eginurainih@students.unnes.ac.id ${ }^{1}$, aseppyu@ mail.unnes.ac.id ${ }^{2}$
}

\begin{abstract}
ABSTRAK
Presiden Republik Indonesia yang ketiga ialah Bacharuddin Jusuf Habibie. Habibie merupakan inspirator pembangkit semangat dalam diri pendengar. Setiap tindak tutur yang disampaikan mampu memberikan informasi dan pernyataan yang bermanfaat. Tindak tutur diartikan sebagai sebuah tindakan mengujarkan tuturan. Tuturan yang Beliau sampaikan sering kali tersaji dalam bentuk video dari saluran YouTube. Siapapun bebas mengakses termasuk penulis. Dengan ini, penulis ingin menganalisis tindak tutur lokusi dalam salah satu video Beliau yang berjudul "Jangan Lelah Belajar" pada saluran YouTube Sang Inspirasi. Tujuan dari Penelitian ini adalah untuk mengkaji dan mencari bentukbentuk tuturan lokusi sesuai ujaran B.J Habibie dalam salah satu video yang berjudul "Jangan Lelah Belajar" pada saluran YouTube Sang Inspirasi. Metode yang digunakan dalam penelitian ini ialah metode deskripsi kualitatif. Data yang dipakai dalam penelitian ini bersumber dari ujaran lisan dan ujaran tertulis yang terdapat dalam video yang berjudul "Jangan Lelah Belajar" pada saluran YouTube Sang Inspirasi. Data dikumpulkan dengan menggunakan teknik menyimak dan mencatat ujaran yang ada. Penelitian ini menghasilkan bentuk tindak tutur lokusi yakni menginformasikan (8), menyatakan (1), menegaskan (1), menjelaskan (1), memberitahu (1), meminta/mengajak (1), dan mengingatkan (1). Selain itu, sebuah ujaran yang menjadi tindak tutur lokusi bisa juga menjadi tindak tutur ilokusi. Setelah adanya penelitian ini, penulis berharap dapat memberikan manfaat pemahaman bagi pembaca terkait tindak tutur lokusi dalam sebuah ujaran, serta menjadi rujukan penelitian-penelitian berikutnya.
\end{abstract}

Kata Kunci: Tindak tutur, lokusi, Pragmatik, B.J Habibie, YouTube.

\section{PENDAHULUAN}

Manusia tidak akan lepas dengan adanya kegiatan komunikasi antar sesama manusia. Komunikasi ini bertujuan untuk memberitahu atau mendapatkan informasi dari ujaran penutur. Ujaran penutur yang kita dengar dapat memberikan informasi terkait suatu hal. Informasi tersebut kita tangkap makna atau maksud ujarannya sehingga dapat dipahami apa yang diinginkan oleh penutur. Kegiatan mengujarkan ujaran terkait sesuatu oleh penutur inilah yang disebut tindak tutur. Gagasan tindak tutur dirintis oleh seorang linguis berkebangsaaan Britania Raya yang bernama John Langshaw Austin. Gagasan tersebut diabadikan dalam buku yang berjudul How to do with world tahun 1962 oleh muridnya setelah dia meninggal. Gagasan ini lalu diteruskan oleh muridnya yang bernama Searle (1969:1975).

Sari (2012) memberikan definisi tentang tindak tutur yakni suatu kalimat sebagai hasil situasi tertentu yang menjadi satuan paling kecil komunikasi berbahasa. Richard (1995) menyebutkan tindak tutur merupakan istilah minimum dari penggunaan peristiwa tutur (dalam Purba, 2011). Menurut Rustono (1999:32) tindak ujar adalah aktivitas mengujarkan atau menuturkan tuturan dengan maksud tertentu. Chaer (2014:50) mendefinisikan tindak tutur sebagai gejala individual yang bersifat psikologis yang ditentukan oleh kemapuan berbahasa si penutur dalam menghadapi situasi tertentu. Pengertian-pengertian di atas dapat disimpulkan bahwa tindak tutur adalah aktivitas mengujarkan suatu kalimat dalam situasi tertentu yang mengandung maksud penutur sesuai dengan kemampuan kebahasaannya. 
Berkaitan dengan tuturan, Austin (dalam Chaer \& Agustina, 2014:53) membagi tindak tutur menjadi tiga, yakni lokusi, ilokusi, dan perlokusi. Penulis hanya akan berfokus pada tindak tutur lokusi. Tindak Lokusi merupakan tindak tutur yang memiliki maksud menyatakan sesuatu (Rustono, 1999:35). Menyatakan sesuatu dalam artian kalimat yang bermakna dan dapat dipahami (Chaer \& Agustina, 2014:53). Lokusi juga diartikan sebagai tuturan yang paling mudah diidentifikasi karena tidak memerlukan konteks tuturan dalam situasi tutur (Lismayanti \& Aswadi, 2018). Dengan ini, tuturan dalam tindak lokusi hanya berkaitan dengan makna, tanpa mengaitkan pada maksud tertentu.

Ujaran yang memiliki makna tertentu, diucapkan oleh tokoh yang berpengaruh akan lebih berarti dan bermanfaat bagi pendengarnya. Salah satu tokoh berpengaruh di Indonesia adalah B.J Habibie. Beliau merupakan Presiden Republik Indonesia ketiga dengan kharisma tinggi. Beliau memiliki segudang prestasi yang mampu menginspirasi bagi banyak orang yang mengetahui perjalanan hidupnya. Selain itu, Beliau sering menyampaikan nasihat-nasihatnya yang mampu memikat pendengarnya. Bisa dikatakan ujaran yang disampaikan Beliau adalah ujaran motivasi. Ujaran motivasi ialah ujaran yang mengandung arah, ketekunan seorang individu, dan intensitas untuk mencapai tujuannya. Ujaran-ujaran yang Beliau sampaikan sering tersaji dalam video atau gambar yang ada di media sosial.

Di era teknologi seperti sekarang ini, media sosial tak lagi asing bagi kebanyakan orang. Pasalnya, media sosial adalah sarana media online yang mempermudah untuk mendapat dan berbagi informasi (Yusi Kamhar \& Lestari, 2019). Media sosial memiliki banyak jenis, salah satu jenis media soaial yakni YouTube. Media tersebut menjadi media informasi yang paling disukai masyarakat. Media ini menyediakan berbagai jenis video atau konten yang beragam. Konten-konten YouTube berisi video pembelajaran, blog video, tata cara memasak, penilaian terhadap sesuatu, musik, hibuaran, dll. Dalam KBBI, konten merupakan sajian informasi melalui produk elektronik atau media (Cecariyani \& Sukendro, 2019).

Berdasarkan pernyataan di atas, dapat diketahui untuk mengakses konten-konten pada media YouTube sangat mudah diakses dan bisa dibuka disituasi apapun. Semua orang bebas mengakses videovideo yang mereka inginkan. Dengan adanya kemudahan ini, penulis tertarik untuk menganalisis tindak tutur lokusi salah satu video yang ada dalam media YouTube. Video tersebut yakni berjudul "Jangan Lelah Belajar" pada saluran YouTube Sang Inspirasi (2019). Oleh karena itu, rumusan masalah penelitian ini yakni: (1) bagimana maksud tuturan yang merupakan tindak tutur lokusi dalam video yang berjudul "Jangan Lelah Belajar" pada saluran YouTube Sang Inspirasi, (2) bagaiman dan apa saja bentuk tuturan tindak tutur lokusi dalam video yang berjudul "Jangan Lelah Belajar" pada saluran YouTube Sang Inspirasi.

Tujuan dari penelitian ini untuk (1) menjelaskan maksud tuturan yang merupakan tindak tutur lokusi dalam video yang berjudul "Jangan Lelah Belajar" pada saluran YouTube Sang Inspirasi, (2) menjelaskan bentuk tuturan tindak tutur lokusi dalam video yang berjudul "Jangan Lelah Belajar" pada saluran YouTube Sang Inspirasi. Penelitian ini bermanfaat untuk menambah wawasan dan pengetahuan terkait maksud dan bentuk tindak tutur lokusi dari ujaran yang ada pada media YouTube. Selain itu, penelitian ini diharapkan mampu menjadi salah satu acuan penelitian tinda tutur lokusi kajian pragmatik. 


\section{TEORI DAN METODOLOGI}

1. Pragmatik

Menurut Morris (1938), pragmatik adalah cabang semiotik yang mempelajari relasi tanda dalam penafsirannya (Levinson 1938:1). Sehingga pragmatik dapat dikatakan sebagai cabang ilmu tanda yang memiliki penafsiran tertentu. Menurut Parker (1986), pragmatik adalah kajian mengenai bagaimana bahasa dipakai untuk berkomunikasi. Menurut Fasold (1991:119), pragmatik adalah kajian mengenai penggunaan konteks untuk menarik inferensi tentang makna. Menutur Mey (1993:5), pragmatik adalah ilmu yang mempelajari bahasa di dalam kaitannya dengan penutur lebih memperjelas batasan bidang ini. Menurut Gunarwan (1994), merumuskan bahwa pragmatik adalah bidang linguistik yang mengkaji hubungan timbal balik antara fungsi ujaran dan bentuk kalimat yang mengungkapkan ujaran.

\section{Tindak Tutur Lokusi}

Menurut Sari (2012) definisi tentang tindak tutur yakni suatu kalimat sebagai hasil situasi tertentu yang menjadi satuan paling kecil komunikasi berbahasa. Richard (1995) menyebutkan tindak tutur merupakan istilah minimum dari penggunaan peristiwa tutur (dalam Purba, 2011). Menurut Rustono (1999:32) tindak ujar adalah aktivitas mengujarkan atau menuturkan tuturan dengan maksud tertentu. Chaer (2014:50) mendefinisikan tindak tutur sebagai gejala individual yang bersifat psikologis yang ditentukan oleh kemapuan berbahasa si penutur dalam menghadapi situasi tertentu. Pengertian-pengertian di atas dapat disimpulkan bahwa tindak tutur adalah aktivitas mengujarkan suatu kalimat dalam situasi tertentu yang mengandung maksud penutur sesuai dengan kemampuan kebahasaannya.

Tindak Lokusi merupakan tindak tutur yang memiliki maksud menyatakan sesuatu (Rustono, 1999:35). Menyatakan sesuatu dalam artian kalimat yang bermakna dan dapat dipahami (Chaer \& Agustina, 2014:53). Lokusi juga diartikan sebagai tuturan yang paling mudah diidentifikasi karena tidak memerlukan konteks tuturan dalam situasi tutur (Lismayanti \& Aswadi, 2018). Dengan ini, tuturan dalam tindak lokusi hanya berkaitan dengan makna, tanpa mengaitkan pada maksud tertentu.

\section{YouTube Sang Inspirasi}

YouTube adalah sebuah situs web berbagi video yang dibuat oleh tiga mantan karyawan PayPal pada Februari 2005. Situs web ini memungkinkan pengguna mengunggah, menonton, dan berbagi video. YouTube "Sang Inspirasi" adalah salah satu saluran youtube yang mengunggah berbagai video inspirasi bagi penonton. Salah satu videonya yakni video "Jangan Lelah Belajar" oleh B.J. Habibie.

Penelitian ini sesuai dengan metode deskripsi kualitatif. Metode ini berguna untuk memberikan gambaran atau representasi mengenai tindak tutur lokusi dalam video yang berjudul "Jangan Lelah Belajar" pada saluran YouTube Sang Inspirasi.

Sumber data diperoleh dari video yang telah diunggah pada media YouTube tanggal 12 September 2019 oleh saluran Sang Inspirasi. Terdapat dua jenis ujaran dalam video tersebut, yakni ujaran lisan yang diujarkan langsung oleh B.J. Habbie dan ujaran yang telah tertulis dalam bentuk gambar yang merupakan kumpula ujaran Beliau. 
Pengumpulan data dilakuakan dengan tahapan berikut ini: (1) melihat dan mendengarkan dengan ungguh-sungguh video yang berjudul "Jangan Lelah Belajar" pada saluran YouTube Sang Inspirasi, (2) mencatat keseluruhan tuturan baik secara lisan maupun tulisan yang ada dalam video, (3) dari hasil catatan tersebut ditentukan data-data yang termasuk tindak tutur lokusi sehingga dapat diteruskan pada tahapan analisis.

Setelah data dikumpulkan, data tersebut dianalisis dengan tahapan berikut ini: (1) data tindak tutur lokusi dibaca dengan sungguh-sungguh, (2) mencari konteks tuturan yang relevan dengan data, (3) membandingkan analisis konteks tuturan yang diperoleh dengan analisis yang telah dilakukan peneliti sebelumnya, (4) menentukan bentuk tindak tutur lokusi yang seseuai dengan analisis, (5) menyususn hasil laporan, (5) dan terakhir membuat kesimpulan.

\section{TEMUAN DAN PEMBAHASAN}

Penelitian ini sesuai dengan tujuan penelitian, yakni untuk (1) menjelaskan maksud tuturan yang merupakan tindak tutur lokusi dalam video yang berjudul "Jangan Lelah Belajar" pada saluran YouTube Sang Inspirasi, (2) menjelaskan bentuk tuturan tindak tutur lokusi dalam video yang berjudul "Jangan Lelah Belajar" pada saluran YouTube Sang Inspirasi. Dalam analisis ditemukan 7 data ujaran lisan dan 7 data ujaran tertulis yang berupa tindak tutur lokusi dalam video yang berjudul "Jangan Lelah Belajar" pada saluran YouTube Sang Inspirasi. Dari keseluruhan data dianalisis berdasarkan konteks tuturannya, sehingga dapat diketahui maksud tuturannya. Dari data tersebut lalu digolongkan ke dalam tujuh bentuk tuturan lokusi, yakni sebagai berikut:

Tabel 1. Bentuk Tindak Tutur Lokusi

\begin{tabular}{|c|c|c|}
\hline No & Bentuk Tindak Tutur Lokusi & Jumlah Tuturan \\
\hline 1. & Menginformasikan. & 8 \\
\hline 2. & Menyatakan & 1 \\
\hline 3. & Menegaskan & 1 \\
\hline 4. & Menjelaskan & 1 \\
\hline 5. & Memberitahu & 1 \\
\hline 6. & Meminta/mengajak & 1 \\
\hline 7. & Mengingatkan & 1 \\
\hline
\end{tabular}

Analisis Tindak Tutur Lokusi Dalam Video “Jangan Lelah Belajar_B.J. Habibie” Pada Saluran YouTube Sang Inspirasi

Berikut adalah 7 data ujaran lisan yang dianalisis sebagai tindak tutur lokusi.

1. Kalau Anda naik sepeda, lalu berhenti anda akan jatuh. Jadi, kalau saya berhenti bekerja, saya mati. Konteks tuturan: 
Analisis tindak tutur lokusi, yakni pengibaratan jika suatu kegiatan tidak dilakukan secara konsisten maka akan hancur. Sama halnya ketika penutur berhenti bekerja maka ia tidak akan mendapat uang, kalau tidak ada uang lama-kelamaan akan mati.

Analisis tersebut memiliki kesamaan dengan analisis yang dilakukan oleh Wiranty (2015). Kesamaannya berupa tindak tutur lokusi yang berfungsi untuk menyampaikan informasi. Pada analisis yang penulis lakukan adalah menginformasikan kalau berhenti berkerja akan mati. Sedangkan, analisis yang dilakukan oleh Wiranty menginformasikan siswa yang datang berjumlah sembilan orang.

2. Kalau ditanya Habibie umurnya sembilan puluh kurang sepuluh, tapi jiwa tujuh belas tahun. Tidak ada bedanya saya umur delapan puluh tahun.

Konteks tuturan:

Analisis tindak tutur lokusi, yakni umur penutur memang sudah tua, tetapi jiwa harus selalu muda. Umur 17 tahun adalah peralihan usia anak-anak menuju dewasa di mana semangat muda itu membara, waktu di mana memulai kehidupan yang sebenarnya.

Analisis tersebut memiliki kesamaan dengan analisis yang dilakukan oleh Yuliana et al., (2013). Keduanya termasuk dalam kategori tindak tutur lokusi menginformasikan tentang suatu hal. Pada analisis yang penulis lakukan adalah menginformasikan usia penutur. Sedangkan, pada analisis Yuliana menginformasikan fakta dan opini.

3. Semangat saya itu datang atas keyakinan dan kesadaran bahwa saya ini manusia, produk dari masyarakat di mana saya hidup.

Konteks tuturan:

Analisis tindak tutur lokusi, yaitu semangat penutur datang dari sebuah keyakinan dan kesadaran bahawa manusia itu adalah produk dari masyarakat. Penutur adalah bagian dari masyarakat itu sendiri. Maka dari itu penutur tidak boleh melupakan hakikatnya sebagai manusia di masyarakat.

Analisis tersebut memiliki kesamaan dengan analisis yang dilakukan oleh Lismayanti \& Aswadi (2018). Keduanya memiliki kesamaan yakni sama-sama menyebutkan kalimat yang berfungsi untuk menyatakan sesuatu. Jika analisis yang penulis lakukan menyatakan bahwa penutur memiliki semangat kesadaran dan keyakinan sebagai bagian dari masyarakat. Sedangkan, analisis yang dilakukan Lismayanti \& Aswadi menyatakan penekanan pihak penjual dan pihak pembeli.

4. Keluarga saya dulu, sekarang, dan masa depan ada bagian masyarakat ini. Kalau masyarakat ini makmur, ya keluarga saya ikut makmur. Karena itu, saya tidak mau berhenti.

Konteks tuturan:

Analisis tindak tutur lokusi, yaitu kehidupan keluarga penutur sejak dulu, hingga sekarang, mauoun masa depan. Fase masa kehidupan adalah bagian dari masyarakat. Jika sebuah masyarakat sejahtera, kemungkinan besar keluarga itu juga akan merasakan kemakmuran. Untuk mencapai sebuah kemakmuaran jangan pernah berhenti, baik berhenti berusaha ataupun berdoa. 
Analisis tersebut memiliki kesamaan dengan analisis yang dilakukan oleh Maharani (2020). Kesamaan yang ada pada keduanya adalah sama-sama menegaskan suatu hal. Pada analisis yang penulis lakukan adalah menegaskan untuk tidak berhenti, sedangkan pada analisis Maharani menegaskan tentang pada orang lain dari pada diri sendiri.

5. Tidak ada gunanya IQ-nya tinggi tapi pemalas, tidak memiliki disiplin, forget it. Yang penting adalah Anda sehat, mau berkorban untuk masa depan yang cerah, anda konsisten, bekerja keras, disiplin, dan bersyukur.

Konteks tuturan:

Analisis tindak tutur lokusi, yaitu IQ tinggi tak menjamin apapun jika malas dan tidak memiliki kedisiplinan. Hal paling penting itu sehat baik jiwa maupun raga, mau untuk berkorban, selalu konsisten, bekerja keras, disiplin, dan tidak lupa bersyukur. IQ tak menjamin apapun tanpa adanya usaha, kerja keras, dan doa.

Analisis tersebut memiliki kesamaan dengan analisis yang dilakukan oleh Qomariyah (2017). Kesamaan tersebut adalah selain sama-sama menginformasikan sesuatu, keduanya juga memiliki fungsi mengajak. Dalam analisis yang dilakukan Qomariyah adalah mengajak siswa untuk menjawab pertanyaan yang diberikan. Sedangkan analisis yang dilakukan oleh penulis adalah mengajak untuk menciptakan hal-hal yang positif.

6. Sejak saya lahir sampai sekarang, saya mampu membuat sinergi positif antara elemen agama, budaya, ilmu pengetauan, dan teknologi.

Konteks tuturan:

Analisis tindak tutur lokusi, yaitu penutur menyampaikan bahwa seseorang harus menciptakan energi positif secara seimbang antara unsur agama, budaya, ilmu pengetahuan, dan teknologi. Setelah singergi positif itu terbentuk dengan nilai-nilai apapun akan membuat kehidupan jauh lebih baik.

Analisis tersebut memiliki kesamaan dengan analisis yang dilakukan oleh Sriharsanti (2020). Kesamaan ini terletak pada analisis tindak tutur lokusi yang sama-sama memberikan informasi terkait sesuatu. Analisis yang diberikan oleh Sriharsanti adalah menginformasikan kepada mitra tutur terkait produk kecantikan. Sedangkan, analisis yang dilakukan penulis adalah untuk menginformasikan pentingnya menciptakan energi positif.

7. Saya bersyukur bisa menyelesaikan semua masalah-masalah yang saya hadapi, masalah dengan hal lain dan terasa orang sekitar manfaatnya. Jadilah mata air yang jernih, yang memberikan kehidupan pada sekitarnya.

Konteks tuturan:

Analisis tindak tutur lokusi, yaitu penutur bersyukur mampu menyelesaikan masalah dan bermanfaat bagi sekitarnya. Keikhlasannya dalam menjadi seseorang yang bermanfaat bagi orang disekelilingnya, menjadi apa yang ingin ia sampaikan kepada pendengarnya. Maka dari itu, penutur berpesan jadilah seorang manusia yang seperti air mampu memberikan kehidupan dan manfaat bagi orang lain. 
Analisis tersebut serupa dengan analisis yang dilakukan Nuardania et al., (2018). Kesamaan tersebut terdapat pada bagian meyampaikan sebuah informasi dan keikhlasan bagi orang yang ada disekitarnya. Jika dalam analisis Nuardania terkait keikhlasan dalam memberikan bantuan kepada anak penyandang difabel. Sedangkan analisis yang dilakukan penulis berkaitan dengan keikhlasan dalam menyelesaikan masalah dalam kehidupan.

Berikut adalah 7 data ujaran tertulis yang dianalisis sebagai tindak tutur lokusi.

1. Apabila kamu sudah memutuskan menekuni suatu bidang. Jadilah orang yang konsisten. Itu adalah kunci keberhasilan yang sebenarnya.

Konteks tuturan:

Analisis tindak tutur lokusi, yakitu ketika menekuni sebuah bidang maka jadilah orang yang konsisten. Jika konsisten dalam bidang itu adalah kunci keberhasilan. Salah satu kunci keberhasilan adalah konsistensi dan ketekunan.

Analisis tersebut memiliki kesamaan dengan analisis yang dilakukan oleh Akbar (2018). Kesamaan terlihat pada bagian analisis tindak asertif yakni tindak tutur yang berfungsi untuk menjelaskan seuatu itu adanya. Analisis Akbar menjelaskan tentang wawancara dengan presiden. Sedangkan analisis yang dilakukan penulis menjelaskan kunci kesuksesan adalah konsistensi dan ketekunan dalam bidang yang digeluti.

2. Keberhasilan bukanlah milik orang pintar. Namun, keberhasilan itu adalah milik mereka yang senantiasa berusaha.

Konteks tuturan:

Analisis tindak tutur lokusi, keberhasilan bukan milik dia yang pintar, tetapi adalah milik dia yang selalu berusaha. Disetiap usaha di situlah ada jalan. Usaha yang telah dilakukan tidak akan pernah menghianati hasil.

Analisis tersebut memiliki kesamaan dengan analisis yang dilakukan oleh Nirmala (2015). Pada analisis yang dilakukanoleh Nirmala terdapat tindak tutur asertif yang memiliki arti menginformasikan tentang suatu hal. Pada analisis yang penulis lakukan, tindak tutur menginformasikan terkait berusaha akan memperoleh keberhasilan. Sedangkan pada analisis yang dilakukan oleh Nirmala adalah menginformasikan tentang suatu tempat.

3. Jangan pernah berhenti mengejar yang kamu impikan, meski apa yang kamu dambakan belum ada di depan mata.

Konteks tuturan:

Analisis tindak tutur lokusi, jangan pernah sekalipun berhenti mengejar apa yang diinginkan, walaupun apa yang dinginkan jauh dari harapan. Terus berusaha dan berjuang dalam mengejar apa yang dinginkan, sejatinya perjuangan mendekatkan hasil yang jauh dari pandangan mata.

Analisis tersebut memiliki kesamaan dengan analisis yang dilakukan oleh Hanggara (2016). Pada keduanya sama-sama merupakan tindak tutur yang berfungsi untuk menginformasikan sesuatu. Pada analisis yang 
dilakuakn oleh penulis menginformasikan untuk tidak berhenti mengejar impian walaupun apa yang dingiinkan masih jauh dari harapan. Sedangkan, pada analisis yang dilakukan oleh Hanggara menginformasikan penutur hanya ingin memotong rambut.

4. Ketika semua orang menghina kamu, itu adalah sebuah pujian. Bahwa selama ini mereka menghabiskan banyak waktu untuk memikirkan kamu, ketika kamu tidak memikirkan mereka.

\section{Konteks tuturan:}

Analisis tindak tutur lokusi, apapun celaan yang kita terima merupakan sebuah pujian. Pujian dalam arti sebagai penggerak kita untuk menjadi lebih baik kedepannya. Sejatinya orang yang mencela kita adalah orang yang paling memperhatikan setiap tingkah laku yang kita lakukan, walaupun kita hanya melakukan kesalahn kecil.

Analisis tersebut memiliki kesamaan dengan analisis yang dilakukan oleh Fitriah \& Fitriani (2017). Kesamaan keduanya terdapat dalam tindak tutur lokusi yang berfungsi untuk memberitahukan.

5. Jadilah pribadi yang selalu siap menjalani setiap rintangan yang datang padamu.

Konteks tuturan:

Analisis tindak tutur lokusi, setiap orang memiliki rintangan dalam hidupnya. Namun, untuk menghadapi rintangan itu kita harus menjadi seseorang yang siap. Siap dalam artian berani menghadapi rintangan itu.

Analisis tersebut memiliki kesamaan dengan analisis yang dilakukan oleh Avidia Ananda et al., (2015). Kesamaan tersebut terdapat pada tindak tutur yang menyatakan untuk meminta mitra tutur terhadap suatu hal. Jika dalam analisis yang dilakukan oleh penulis meminta mitra tutur untuk menjadi pribadi yang siap dalam menghadapi apapun. Sedangkan, dalam analisis yang dilakukan oleh Avidia adalah meminta mitra tutur untuk mendengar ujaran dalam iklan.

6. Salah satu kunci keberhasilan adalah menggunakan uang Anda untuk pengalaman, bukan untuk keinginan.

Konteks tuturan:

Analisis tindak tutur lokusi, uang bagi sebagian orang memang segalanya. Akan tetapi, terkadang orang menghabiskan uang itu hanya untuk keingan. Padahal, uang bisa menjadi salah satu kuci keberhasilan jika digunakan untuk pengalaman.

Analisis tersebut memiliki kesamaan dengan analisis yang dilakukan oleh Nuryatin (2015). Kesamaan dari keduanya itu terlihat dalam tindak tutur yang mengingatkan. Nuryatin menuliskan dalam analisisnya, tokohtokoh yang ada dalam novel mengingatkan kebaikan. Sedangkan, analisis yang dilakukan oleh penulis adalah mengingatkan dalam hal mengatur uang untuk hal yang lebih berguna.

7. Dimanapun kamu berada, selalulah menjadi yang terbaik, dan berikan yang terbaik yang bisa kamu berikan.

Konteks tuturan: 
Analisis tindak tutur lokusi, dimanapun kita berada harus terus berusaha menjadi yang terbaik. Karena dengan kita menjadi terbaik, kita juga akan bisa memberikan yang terbaik untuk orang sekeliling kita.

Analisis tersebut memiliki kesamaan dengan analisis yang dilakukan oleh Dwi \& Zulaeha (2017). Kesamaan tersebut terdapat pada modus deklaratif, yakni modus yang berisi tentang memberikan informasi dari penutur kepada mitra tutur.

\section{KESIMPULAN}

Tindak tutur adalah kegiatan mengujarkan ujaran dari penutur kepada mitra tutur, tindak tutur lokusi adalah tindak tutur yang memiliki makna untuk menyatakan sesuatu. Pada analisis yang penulis lakukan oleh penulis medapatkan tujuh data ujaran lisan dan tujuh data ujaran tertulis. Dari data-data yang ditemukan terdapat banyak bentuk tindak tutur lokusi yang telah dianalisis. Bentuk tindak tutur lokusi yang ditemukan antara lain tindak tutur menginformasikan (8), menyatakan (1), menegaskan (1), menjelaskan (1), memberitahu (1), meminta/mengajak (1), dan mengingatkan (1). Selain itu, sebuah ujaran yang merupakan tindak tutur lokusi bisa menjadi tindak tutur ilokusi tergantung konteks yang mengikutinya.

\section{DAFTAR PUSTAKA}

Akbar, S. (2018). Analisis Tindak Tutur pada Wawancara Putra Nababan dan Presiden Portugal (Kajian Pragmatik). SeBaSa, 1(1), 27. https://doi.org/10.29408/sbs.v1i1.792

Avidia Ananda, N., Sutama, I. M., \& Nurjaya, I. G. (2015). Bentuk dan Fungsi Tindak Tutur Slogan Varian Iklan Pond's di Televisi Swasta. Journal JJPBS Universitas Pendidikan Ganesha Jurusan Pendidikan Bahasa Dan Sastra Indonesia, 3(1).

Cecariyani, S. A., \& Sukendro, G. G. (2019). Analisis Strategi Kreatif dan Tujuan Konten Youtube (Studi Kasus Konten prank Yudist Ardhana). Prologia, 2(2), 495. https://doi.org/10.24912/pr.v2i2.3735

Chaer, A., \& Agustina, L. (2014). Sosiolinguistik Perkenalan Awal (Revisi). Rineka Cipta.

Dwi, L., \& Zulaeha, I. (2017). Tindak Tutur Ekspresif Humanis dalam Interaksi Pembelajaran di SMA Negeri 1 Batang: Analisis Wacana Kelas. Seloka: Jurnal Pendidikan Bahasa Dan Sastra Indonesia, 6(2), 111-122.

Fitriah, F., \& Fitriani, S. S. (2017). Analisis Tindak Tutur dalam Novel Marwah di Ujung Bara Karya R.H. Fitriadi. Master Bahasa, 5(1), 51-62.

Hanggara, B. D. (2016). Analisis Tindak Tutur Dalam Cerita Bersambung Lintang-Lintang Dadi Seksi Karya Sawitri Dalam Majalah Djaka Lodang Tahun 2013. 03, 1-10.

Inspirasi, S. (2019). Jangan Lelah Belajar B.J. Habibie. https://youtu.be/XjWKe-oGjc4

Lismayanti, H., \& Aswadi, D. (2018). Tindak Tutur Lokusi Pedagang dan Pembeli di Pasar Sudi Mampir Banjarmasin. STILISTIKA: Jurnal Bahasa, Sastra, Dan Pengajarannya, 3(1), 98-106. https://doi.org/10.33654/sti.v3i1.510

Maharani Annisa Tetty, A. P. Y. U. (2021). Analisis Tindak Tutur Lokusi Twit Akun Twitter Fiersa Besari. METAFORA, VI, 86-101. http://jurnalnasional.ump.ac.id/index.php/METAFORA/article/view/7819

Nirmala, V. (2015). Tindak Tutur Ilokusi pada Iklan Komersial Sumatera Ekspress. Kandai, 11(2), 139-150. http://ojs.badanbahasa.kemdikbud.go.id/jurnal/index.php/kandai/article/view/222

Nuardania, C., Kusumaningsih, D., \& Sugiyantoc, Y. (2018). Kekuatan Tindak Tutur Ekspesif Dalam Talk Show Kick Andy. Prosiding Senasbasa (Seminar Nasional Bahasa Dan Sastra), 66-76. 
Nuryatin, A., \& Artikel, I. (2015). Tindak Tutur Direktif Dalam Wacana Novel Trilogi Karya Agustinus Wibowo. Seloka: Jurnal Pendidikan Bahasa Dan Sastra Indonesia, 4(2), 78-85.

Purba, A. (2011). Tindak Tutur dan Peristiwa Tutur. Pena: Jurnal Pendidikan Bahasa Dan Sastra, 1(1), $77-$ 91. https://online-journal.unja.ac.id/pena/article/view/1426

Qomariyah, L. (2017). Tindak Tutur Direktif Guru Dalam Pembelajaran Bahasa Arab. Arabi : Journal of Arabic Studies, 2(1), 1. https://doi.org/10.24865/ajas.v2i1.32

Rustono. (1999). POKOK-POKOK PRAGMATIK. CV IKIP Semarang Press.

Sari, F. D. P. (2012). Tindak Tutur Dan Fungsi Tuturan Ekspresif Dalam Acara Galau Nite Di Metro Tv: Suatu Kajian Pragmatik. Skriptorium, 1(2), 1-14.

Sriharsanti, A. Y. D., \& Utomo, A. P. Y. (n.d.). Analisis Tindak Tutur pada Iklan Produk Pond's Tone Up Cream di Youtube. 294-301. https://ejournal.hikmahuniversity.ac.id/index.php/lentera/article/view/309/155

Wiranty, W. (2015). Tindak Tutur dalam Wacana Novel Laskar Pelangi Karya Andrea Hirata (Sebuah Tinjauan Pragmatik). Jurnal Pendidikan Bahasa, 4(2), 294-304. Tindak Tutur dalam Wacana Novel Laskar Pelangi Karya Andrea Hirata (Sebuah Tinjauan Pragmatik)

Yuliana, R., Rohmadi, M., \& Suhita, R. (2013). Daya Pragmatik Tindak Tutur Guru Dalam Pembelajaran Bahasa Indonesia Pada Siswa Sekolah Menengah Pertama. BASASTRA Jurnal Penelitian Bahasa, Sastra Indonesia Dan Pengajarannya, 2(1), 1-14.

Yusi Kamhar, M., \& Lestari, E. (2019). Pemanfaat Sosial Media Youtube Sebagai Media Pembelajaran Bahasa Indonesia DI Perguruan Tinggi. Inteligensi: Jurnal Ilmu Pendidikan, 1(2), 1-7. https://doi.org/10.33366/ilg.v1i2.1356 